\title{
MUC5AC Gene
}

National Cancer Institute

\section{Source}

National Cancer Institute. MUC5AC Gene. NCI Thesaurus. Code C90332.

This gene plays a role in the protection of the respiratory and gastrointestinal tracts. 